\title{
Preparation of a Nutritious and Healthy RTD (Ready to Drink) Beverage Enriched with Natural Anti Oxidants
}

\author{
Srishti Saklani, Mahipal Singh Tomar* and Shumaila Siddiqui \\ Department of Food Technology, Uttaranchal College of Applied and Life Science, \\ Uttaranchal University, Dehradun, 248007, Uttarakhand, India \\ *Corresponding author
}

\section{A B S T R A C T}

Over the past few years, the Beverage Industry has evolved and innovated itself to meet the demands of the consumers and the present market. Earlier people had only water and milk as a beverage. Water is considered to be a source of hydration while milk is

Keywords

Drinks, Cumin, Antioxidant

Article Info

Accepted:

17 April 2019

Available Online:

10 May 2019 considered as "complete food", but the advancements in the food sector has led to the manufacture and processing of many beverages, either alcoholic or non-alcoholic. Apart from alcoholic drinks, the trend is readily shifting towards RTD (Ready to Drink) beverages. These are low-fat drinks that are thirst-quenching, refreshing, and nutritionally superior and provide instant energy. Drinks infused with herbal extracts can be a potential source of anti-oxidants, vitamins, minerals and fibres. This paper focuses on RTD beverage made primarily from coconut water, coriander leaves extract and cumin powder. Coconut water is a primitive tropical beverage whose demand and popularity in the market is elevating continuously. It has been characterized as a "sports beverage". It has low matter content comprising mainly of sugars and minerals. Coriander leaves are the source of essential oil, Linalool. Besides, the leaves possess anti-microbial, anti-fungal, antimutagenic and anti-oxidant properties and help to cure indigestion, depression and lowering cholesterol levels. Cumin is a dried ripe food with a strong aromatic flavour. It has high medicinal value as well as possessing anti-microbial and anti-oxidant properties.

\section{Introduction}

Drinks are referred to as beverages that are appetizing, easily digestible, thirst-quenching that people consume all over the world to satisfy their needs in terms of energy, nutrition, hydration, and refreshment. Fruit beverages include natural and sweetened juices, squash, cordial, nectars, concentrates, citrus juices, barley water, RTD beverages, etc. (Sudheer and Indira, 2007). Soft drinks and juices are nutritionally superior above the synthetic beverages and help to replace the lost salts of the body. There are two sets of regulations for the Beverage Industry: Soft Drink Regulation, 1964 and Fruit Juices, and Fruit Nectars Regulation, 1977. Both the set of regulations are responsible for monitoring and checking the composition, description and the class of the food material. In today's era, RTD beverages are growing consistently and innovating itself to newer trends to meet 
the demands of the consumers. Nowadays, people are more concerned for their health and well-being, therefore, the newer trend of the Beverage Industry is readily shifting towards the natural extracts that are being infused in the drinks and juices (mint extract, ginger extract, etc.). Such herbal beverages and natural beverages improve the mineral content, vitamins, functional properties as well as the organoleptic properties of the drink (De et al., 2007).

The present paper discusses RTD beverage comprising of tender coconut water, coriander leaves extract and cumin. The perfect blend of these ingredients would result in a healthy, refreshing and nutritionally superior drink over other carbonated and aerated beverages, also it will be a potential source of vitamins, minerals, energy, amino acids, and sugar.

The endosperm is the edible part of the coconut fruit. During cellularization process, the embryo isn't filled completely leaving a liquid behind mainly called "Coconut Water" (Janick and Paull, 2008). Tender coconut water is a refreshing, rehydrating and thirstquenching liquid. It contains sugars, vitamins, minerals, growth hormones, proteins and amino acids (Shaw and Shrivastava, 1963). It is a source of plenty of minerals like sodium, potassium, zinc, copper, boron, chloride, phosphorus, zinc, manganese, etc. the major minerals present in coconut water serving as body electrolytes too are sodium and potassium. Coconut water is generally consumed and is prescribed against gastritis, indigestion, hiccups, and bladder infections. It also acts as the source of calcium for lactating mothers.

Among the oldest herbs, Coriander (Coriandrum sativum L) belongs to the Apiaceae family and comes in mainly two varieties: vulgar and microcarpum (Burdock and Carabin, 2009). They are used primarily in garnishing the foods and also have medicinal value (Opkyde, 1973). The essential oil content of the leaves is about $1 \%$ comprising of linalool, comprising the main component (Wichtl, 1994). The leaves are reported to have a moisture content of $87.9 \%$, protein content of $3.3 \%$, carbohydrate content (total sugar) of $6.5 \%$ and a total ash content of $1.7 \%$ (Ganesan et al., 2013). It is extensively advantageous in curing deficiencies of iron and vitamins. Like all green leafy vegetables, it is a good source of vitamins, minerals, betacarotene, and dietary fibre. It is referred to as "Dhania" in Hindi and is recommended for treating digestive tract disorders, urinary tract disorders, and respiratory tract disorders.

The non-leafy part of the plant (bud, bark, seed, fruit, etc.) is referred to as a spice. They are used to season foods, acts as a preservative and may also be used as herbal medicine. They are composed of ash, fibre, carbohydrates, and essential oils. Cumin (Cuminum cyminum) is a flowering plant in the family Apiaceae. The essential oil present in cumin is responsible for its characteristic aroma and flavour. The spice is an important ingredient of Indian sub-continent and is reported to be popular in the Roman cuisines (Peter, 2001; Raghavan, 2007). It has preservative (Peter, 2001) and anti-oxidant properties as well (Thippeswamy et al., 2005). It is used in the treatment of wounds, flatulence, dyspepsia, diarrhoea, and indigestion. Spices are an excellent source of antioxidants, and some of them even outperform the synthetic antioxidants and are safer also from the health point of view.

\section{History of beverages}

Juices are consumed all over the world as a beverage or along with food to add flavour. It has become possible to preserve the juices and beverages without fermentation (for wine, beer, etc.) with the invention of pasteurization. Hence, the trend of natural and non-alcoholic beverages has entered the 
market. The earliest evidence for juice production is grape pits of $8000 \mathrm{BCE}$. However, it is impossible to distinguish whether these grapes were used for wine production or juice production (Johnson, 1989). During the $16^{\text {th }}$ century, the first produced juice was lemonade in Italy. Soon after orange juice emerged the market in the $17^{\text {th }}$ century (Emmins, 2000). Later "sharbat" was also in the mid $17^{\text {th }}$ century. They were cool and refreshing drinks that came from Turkey (Emmins, 2000).

Over the past 100 years, innovations have been made in the Fruit Juice Industry that has introduced fruit juice concentrates and the use of Pasteurization. For the very first time, pasteurization was applied to preserve the juices in 1869 by Dr. Thomas B. Welch, allowing a longer shelf life to the juices without fermenting them. Welch started this process on juices just a few years after it was invented but years before it was applied to milk regularly (Welch's Company history).

Juice concentrates came during World War II for providing instant energy to the troops. Many fortified drinks and juices are replacing the soft drinks in the market. Along with vitamins and minerals, Spirulina, blue-green algae, and herbs such as Echinacea are also being incorporated in the juices (Nicholl, 1998).

The first masticating juicer was invented in the mid-1950s, the Champion Machine. It worked on the principle of heating the juice to kill the enzymes by making use of a highspeed centrifuge (4000rpm). Most of the nutrients were also lost during the process due to the heat formed.

In 1993, the world's first twin gear extractor called The Green Power Juicer was produced. It worked on the principle of pressing and extracting the maximum amount of juice along with the nutrients without losing them to heat.

\section{Process of the RTD beverage}

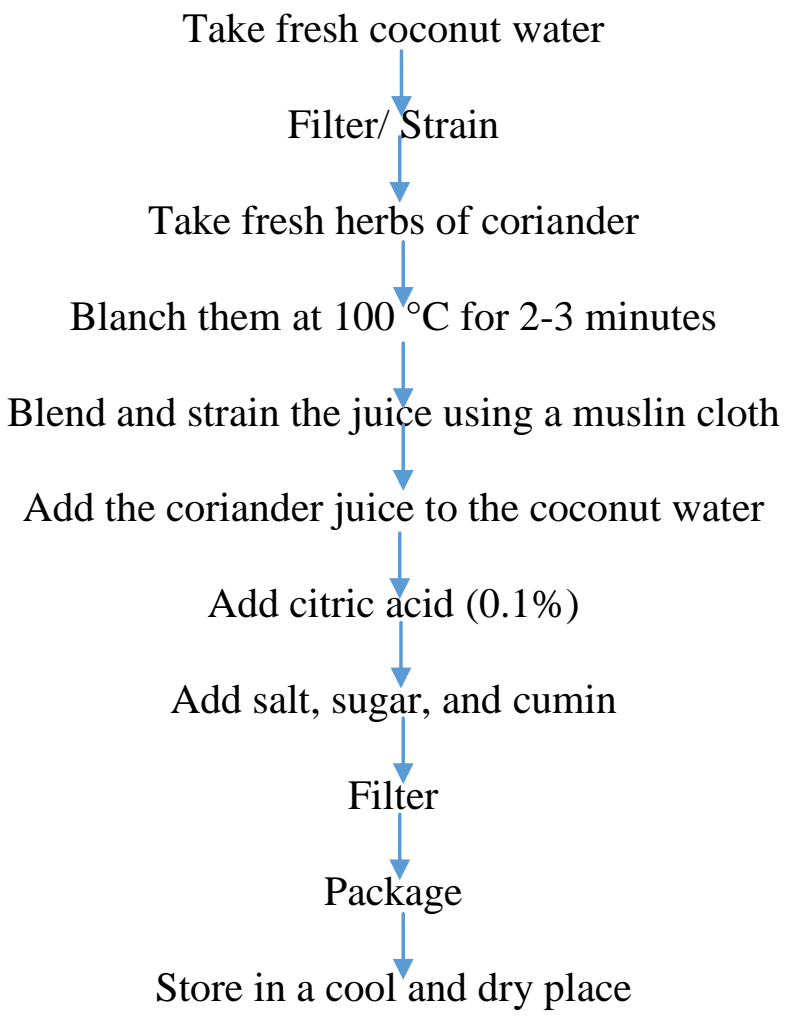

\section{Properties}

\section{Coconut water}

Coconut water comprises of $95.5 \%$ water, $4 \%$ sugars, $0.1 \%$ fat, $0.02 \%$ calcium, $0.01 \%$ phosphorous, $0.5 \%$ iron, considerable amounts of amino acids, mineral salts, vitamin B complex, vitamin $\mathrm{C}$ and cytokines, etc. (Vigliar et al., 2006). It is a rich source of magnesium, potassium and vitamin $\mathrm{C}$, which are known to reduce the risk for coronary heart disease (Anurag and Rajamohan, 2003). It is a major source of the free amino acid Larginine, which has vasodilator function (Boger and Bode-Boger, 2001). The antioxidant properties on four samples of coconut water obtained by hydro distillation and by solvent extraction using petroleum ether at 
different concentrations were assessed (Fonseca et al., 2009).

\begin{tabular}{|c|c|c|c|c|}
\hline S.No. & Sample & $\begin{array}{l}\text { Mode } \\
\text { of } \\
\text { Extrac } \\
\text { tion }\end{array}$ & $\begin{array}{l}\text { Concentr } \\
\text { ation } \\
(\mu \mathrm{g} / \mu \mathrm{l})\end{array}$ & $\begin{array}{l}\text { Antioxi } \\
\text { dant } \\
\text { Activity } \\
(\%)\end{array}$ \\
\hline \multirow[t]{4}{*}{1.} & \multirow[t]{4}{*}{ A } & \multirow{4}{*}{$\begin{array}{l}\text { Hydro- } \\
\text { distillat } \\
\text { ion }\end{array}$} & 1 & 79.4 \\
\hline & & & 0.50 & 76.6 \\
\hline & & & 0.25 & 64.8 \\
\hline & & & 0.125 & 41.2 \\
\hline \multirow[t]{4}{*}{2.} & \multirow[t]{4}{*}{ B } & \multirow{4}{*}{$\begin{array}{l}\text { Hydro- } \\
\text { distillat } \\
\text { ion }\end{array}$} & 1 & 83.5 \\
\hline & & & 0.50 & 79.3 \\
\hline & & & 0.25 & 67.2 \\
\hline & & & 0.125 & 32.5 \\
\hline \multirow[t]{2}{*}{3.} & \multirow[t]{2}{*}{$\mathrm{C}$} & \multirow{2}{*}{$\begin{array}{l}\text { Solvent } \\
\text { extracti } \\
\text { on }\end{array}$} & 1 & 31.5 \\
\hline & & & 0.25 & 16.4 \\
\hline \multirow[t]{2}{*}{4.} & \multirow[t]{2}{*}{ D } & \multirow{2}{*}{$\begin{array}{l}\text { Solvent } \\
\text { extracti } \\
\text { on }\end{array}$} & 1 & 34.9 \\
\hline & & & 0.25 & 27.7 \\
\hline
\end{tabular}

\section{Coriander leaves}

The leaves of coriander are a source of protein, vitamins, minerals (calcium, phosphorus, iron, etc.), fibers and carbohydrates. The leaves seeds contain an essential oil (EO)which provides a characteristic flavour to the leaves and also acts as a preservative (Kalemba, 2003). Ganesan et al., reported that coriander leaves are rich in moisture $(87.9 \%)$, protein $(3.3 \%)$, carbohydrates (total sugar $6.5 \%$ ) and total ash $1.7 \%$. The coriander seed essential oil is also used as a food supplement within limitable amounts of $600 \mathrm{mg} /$ day (EFSA Panel on Dietetic Products).

The coriander seed essential oil helps in controlling blood glucose level and held promising for being used as an antihyperglycemic agent (Gallahgher, 2003).

\section{Anti-microbial properties of coriander}

The essential oil of the coriander seeds and leaves inhibit anti-bacterial properties against gram (+ve) and gram (-ve) food spoilage bacteria (Delaquis et al., 2002). It has been studied that coriander leaves exhibit inhibitory effects on potential food spoilage bacteria such as Klebsiella pneumonia, Bacillus megaterium, Pseudomonas aeruginosa (Keksin et al., 2011). The antibacterial properties of coriander could be due to the presence of linalool, an important component of essential oil which has been reported to have an anti-bacterial effect against many strains (Ates et al., 2003). An anti-microbial peptide containing 26 amino acids namely Plantaricin $C$. sativum has been isolated from coriander leaf extract is reported to exhibit anti-microbial properties against gram (+ve) and gram (-ve) bacteria with Minimum Inhibitory Concentration (MIC) of 71.55 and $86.4 \mu \mathrm{g} / \mathrm{ml}$ respectively against K.pneumoniae and P.aeruginosa (ZareShehneh et al., 2014). The Total Phenolic Content (TPC) in coriander leaves was found to be $1.12 \mathrm{mg}$ GAE $/ 100 \mathrm{ml}$. The phenolic compounds are beneficial against chronic diseases (Forester and Warehouse, 2009). Such beneficial effects of coriander are due to the anti-radical and anti-oxidant properties of its phenolic compounds (Lurton, 2013). The anti-oxidant assays found to be in coriander leaves is $26.82 \%$.

\section{Anti-oxidant properties of coriander}

Coriander like all other spices inhibits antioxidant properties which increases the shelflife of food. The radical scavenging activity (RSA) of coriander seed essential oil (CSEO) $(500 \mu \mathrm{g})$ was $66.48 \%$ while that of coriander leaves essential oil was $56.73 \%$ (Shahwar et al., 2012). (Sriti et al., 2011) reported that the RSA of the methanolic extracts of coriander leaves was higher than the synthetic antioxidants frequently used in industries, i.e., BHA and BHT. The CSEO and CLEO can be used as a natural source of anti-oxidants in lipid-containing food as well (Ramadan et al., 2003). The extracts possessing a high level of amino acids can be used to prevent oxidative 
deterioration of food (Wangensteen et al., 2004).

\section{Food preservation and anti-spoilage}

The oxidation of lipids causes rancidity which is characterized by off-odour, unpleasant taste and also changes the nutritional value of the food (Iqbal-Bhanger et al., 2008). BHA and BHT are used as antioxidants to prevent oxidation (Reddy et al., 2005) but they have been reported for their carcinogenic properties and causes serious illness like liver damage (Nanditha et al., 2008). C. sativum possess excellent anti-microbial, anti-fungal, and antioxidant properties. EO plays a great role in food preservation. $C$. sativum is stable at high temperatures and can be used as a substitute for BHA and BHT. An Italian processed food, Salami, with coriander essential oil, remained stable during the entire period of storage maintain Peroxide Value and TBARS value as compared to product without coriander essential oil, the coriander essential oil had a stronger effect on the product as compared to BHT on retardation of lipid oxidation and thus increasing the shelf life (Marangoni et al., 2011).

\section{Cumin}

The most common spice cumin belongs to the Apiaceae family and is used as a flavouring agent in many cuisines. Spices have been proven to be an evergreen source of antioxidants, anti-microbial and for their medicinal value (Raghavan, 2007). The tremendous anti-microbial properties of cumin have been well known since ancient times. Researches have concluded that the seed extracts inhibit the growth of E. coli, $B$. subtilis, S. feacalis (Saxena and Vyas, 1986).

\section{Anti-oxidant properties of cumin}

Spices are most popularly known for their anti-oxidant properties. Studies reveal that the methanolic extracts of cumin showed higher anti-oxidant properties as compared to the aqueous extracts (Thipperswamy and Naidu, 2005).

The anti-oxidant and phenolic compounds vary in cumin according to the maturity of the seeds. The Radical Scavenging Activity (RSA) of the cumin's essential oil showed greater value than BHA and BHT at a concentration of $240 \mu \mathrm{g} / \mathrm{ml}$ the inhibition percentage reached $85.4 \%$, this might be due to the presence of antioxidant compounds present in cumin such as cuminal, $\gamma$-terpinene, pinocarveol, earatol and linalool (El-Ghorab et al., 2010; Rahman et al., 2015).

Depending upon the solvent used for extraction, the Total Phenolic Compounds (TPC) in cumin seeds varies from 9 to 35.3 $\mathrm{mg}$ of gallic acid per gram of the dry weight (mg of GAE/gm of dry weight) while the Total Flavonoid Content (TFC) in cumin varies from 0.4 to $5.6 \mathrm{mg}$ catechin equivalent per gram of the dry weight ( $\mathrm{mg}$ of CE/gm of the dry weight). The percent antioxidant activity at different time periods for cumin, BHA and BHT were as follows (SayedAhmad, B. et al., 2017):

\begin{tabular}{|c|c|c|c|c|}
\hline & \% In & ion & & \\
\hline $\begin{array}{l}\text { Antioxi } \\
\text { dant } \\
\text { Agent }\end{array}$ & $30 n$ & $60 \mathrm{~min}$ & $90 \mathrm{~min}$ & $\begin{array}{l}120 \\
\text { min }\end{array}$ \\
\hline Cumin & $\begin{array}{l}9.27 \\
\pm 0.2\end{array}$ & $\begin{array}{l}36.67 \pm \\
0.2\end{array}$ & $\begin{array}{l}36.5 \pm \\
0.46\end{array}$ & 0.4 \\
\hline $\begin{array}{l}\text { BHT } \\
(1 \mathrm{mM})\end{array}$ & $\begin{array}{l}12.67 \pm \\
0.18\end{array}$ & $\begin{array}{l}35.12 \pm \\
0.28\end{array}$ & $\begin{array}{l}33.60 \pm \\
0.21\end{array}$ & $\begin{array}{l}49.90 \pm \\
0.49\end{array}$ \\
\hline $\begin{array}{l}\text { BHA } \\
(1 \mathrm{mM})\end{array}$ & $\begin{array}{l}21.77 \pm \\
0.28\end{array}$ & $\begin{array}{l}41.99 \pm \\
0.28\end{array}$ & $\begin{array}{l}42.95 \pm \\
0.25\end{array}$ & $\begin{array}{l}57.72 \pm \\
0.32\end{array}$ \\
\hline
\end{tabular}

The phenol component of cumin essential oil was reported to be $0.21 \pm 0.01 \mu \mathrm{g}$ of GAE/mg (Milan et al., 2008) while the total phenolic content of cumin reported being $75 \pm 1 \mu \mathrm{g}$ GAE/mg extract solids (Ho et al., 2008). 


\section{The anti-bacterial effect of cumin}

The anti-bacterial effect of cumin extract was analyzed against some food spoilage pathogens, E. coli, S. aureus, and S. faecalis while Pseudomonas and Klebsiella species were resistant against cumin extract. After analyzing the complete death time on the exposure of cumin oil on E. coli, S. aureus and $S$. faecalis for 30, 90 and 120 minutes respectively it was concluded that $E$. coli is the most pregnable micro-organism and $S$. faecalis is least pregnable. After determining the minimal inhibition concentration (MIC) and minimal bactericidal concentration (MBC), it was observed that E. coli is the most sensitive micro-organism with the lowest MBC value $(1 \mu \mathrm{l} / \mathrm{ml})$. Greater the ratio of the duration of time (min) to the zone inhibition $(\mathrm{mm})$, greater is the resistance of the micro-organism to the lethal effect of the cumin extract.

In conclusion, talking about the health of people today, suffering from various diseases like hypertension, diabetes, gastrointestinal disorders, thyroid, etc. that are more inclined toward the chemically processed food, makes it a concern for the food industry for their use of synthetic and artificially produced products. Ready to drink beverages are a high source of energy, minerals, and vitamins, they are highly refreshing. Drinks infused with herbal extracts and natural products are highly replenishing, source of anti-oxidants and many essential oils. This paper shows that the final RTD comprising of coconut water, coriander extract, and cumin would prove to be efficiently effective to health by possessing anti-bacterial properties, anti-oxidant properties and a source of a number of vitamins and minerals. RTD beverages with other herbal extracts and the use of natural products will provide the food industry and beverage industry with new possibilities.

\section{References}

Anurag, P., and Rajamohan, T. (2003). Cardioprotective effect of tender coconut water in experimental myocardial infarction. Plant Foods for Human Nutrition, 58(3), 1-12.

Ates, D. A., and Erdogrul, O. T. (2003). Antimicrobial Activities of Various Medicinal and Commercial Plant Extracts. Turkish Journal of Biology, 27(3).

Bhanger, M. I., Iqbal, S., Anwar, F., Imran, M., Akhtar, M., and Zia- ul- Haq, M. (2008). Antioxidant potential of rice bran extracts and its effects on stabilisation of cookies under ambient storage. International journal of food science \& technology, 43(5), 779-786.

Böger, R. H., and Bode-Böger, S. M. (2001). The clinical pharmacology of Larginine. Annual review of pharmacology and toxicology, 41(1), 79-99.

Burdock, G. A., and Carabin, I. G. (2009). Safety assessment of coriander (Coriandrum sativum L.) essential oil as a food ingredient. Food and Chemical Toxicology, 47(1), 22-34.

Campbell-Falck, D., Thomas, T., Falck, T. M., Tutuo, N., and Clem, K. (2000). The intravenous use of coconut water. The American journal of emergency medicine, 18(1), 108-111.

De Carvalho, J. M., Maia, G. A., De Figueiredo, R. W., De Brito, E. S., and Rodrigues, S. (2007). Development of a blended nonalcoholic beverage composed of coconut water and cashew apple juice containing caffeine. Journal of Food Quality, 30(5), 664-681.

Delaquis, P. J., Stanich, K., Girard, B., and Mazza, G. (2002). Antimicrobial activity of individual and mixed fractions of dill, cilantro, coriander and eucalyptus essential oils. International 
journal of food microbiology, 74(1-2), 101-109.

El-Ghorab, A. H., Nauman, M., Anjum, F. M., Hussain, S., and Nadeem, M. (2010). A comparative study on chemical composition and antioxidant activity of ginger (Zingiber officinale) and cumin (Cuminum cyminum). Journal of agricultural and food chemistry, 58(14), 8231-8237.

Emmins C., Kiple K.F, and Ornelas K.C (2000). The Cambridge World History of Food. Cambridge University Press: Cambridge, UK; New York, pp. 702712.

Evans, P., and Halliwell, B. (2001). Micronutrients: oxidant/antioxidant status. British journal of nutrition, 85(S2), S67-S74.

Fonseca, A. M. D., Bizerra, A., Souza, J. S. N. D., Monte, F. J. Q., Oliveira, M. D. C. F. D., Mattos, M. C. D., and Lemos, T. L. (2009). Constituents and antioxidant activity of two varieties of coconut water (Cocos nucifera L.). Revista Brasileira de Farmacognosia, 19(1B), 193-198.

Forester, S. C., and Waterhouse, A. L. (2009). Metabolites are key to understanding health effects of wine polyphenolics. The Journal of nutrition, 139(9), 1824S$1831 \mathrm{~S}$

Gallagher, A. M., Flatt, P. R., Duffy, G., and Abdel-Wahab, Y. H. A. (2003). The effects of traditional antidiabetic plants on in vitro glucose diffusion. Nutrition research, 23(3), 413-424.

Ganesan, P., Phaiphan, A., Murugan, Y., and Baharin, B. S. (2013). Comparative study of bioactive compounds in curry and coriander leaves: An update. $J$ Chem Pharm Res, 5(11), 590-4.

Ho, S. C., Tsai, T. H., Tsai, P. J., and Lin, C. C. (2008). Protective capacities of certain spices against peroxynitritemediated bimolecular damage. Food and Chemical Toxicology, 46(3), 920928.

Janick, J., and Paull, R.E. (2008): The Encyclopedia of Fruit \& Nuts; CAB International: Wallingford, UK, p. 112.

Jayalekshmy, A. (1986). Changes in the chemical composition of coconut water during maturation. J Lipid Res, 27, 114120.

Johnson, H. (1989). Vintage: The story of wine. Simon and Schuster.

Kalemba, D. A. A. K., and Kunicka, A. (2003). Antibacterial and antifungal properties of essential oils. Current medicinal chemistry, 10(10), 813-829.

Keskin, D., and Toroglu, S. (2011). Studies on antimicrobial activities of solvent extracts of different spices. Journal of Environmental Biology, 32(2), 251-256.

Lurton, L. (2003). Grape polyphenols: New powerful health ingredients. Innovations in Food Technology, 18, 28-30.

Marangoni, C., and Moura, N. F. D. (2011). Antioxidant activity of essential oil from Coriandrum sativum L. in Italian salami. Food Science and Technology, 31(1), 124-128.

Milan, K. M., Dholakia, H., Tiku, P. K., and Vishveshwaraiah, P. (2008). Enhancement of digestive enzymatic activity by cumin (Cuminum cyminum L.) and role of spent cumin as a bionutrient. Food Chemistry, 110(3), 678-683.

Nanditha, B. R., Jena, B. S., and Prabhasankar, P. (2009). Influence of natural antioxidants and their carry- through property in biscuit processing. Journal of the Science of Food and Agriculture, 89(2), 288-298.

Nicholls W. (1998). Drinking your vitamins (and minerals). The Washington Post; Sect. E07.

Oliveira, H. D. J. S., Abreu, C. M. P. D., Santos, C. D. D., Cardoso, M. D. G., Teixeira, J. É. C., and Guimarães, N. C. 
C. (2003). Carbohydrate measurements on four brands of coconut water. Ciência e Agrotecnologia, 27(5), 10631067.

Opkyde, D. L. G. (1973). Monographs on fragrans raw materials: Coriander oil. Food Cosm Toxicol, 11, 1077.

Peter, K. V. 2001. Handbook of herbs and spices Vol. 1. Woodhead Publishing Limited Abington Hall, Abington Cambridge, England.

Raghavan, S. (2000). Handbook of spices, seasonings and flavorings. CRC press.

Raghavan, S. 2007. Handbook of spices, seasonings, and flavorings. 2nd Ed. CRC Press, Taylor \& Francis Group, Boca Raton.

Rahman, A., Islam, R., Azad, M. A. K., Dalal, M. H., Rahman, M. S., and Sattar, M. A. (2015). Chemical composition, antioxidant activity and total phenolics of the seeds of Cuminum cyminum L. Journal of Characterization and Development of Novel Materials, 7(1), 1.

Ramadan, M. F., Kroh, L. W., and Mörsel, J. T. (2003). Radical scavenging activity of black cumin (Nigella sativa L.), coriander (Coriandrum sativum L.), and niger (Guizotia abyssinica Cass.) crude seed oils and oil fractions. Journal of agricultural and food chemistry, 51(24), 6961-6969.

Reddy, V., Urooj, A., and Kumar, A. (2005). Evaluation of antioxidant activity of some plant extracts and their application in biscuits. Food Chemistry, 90(1-2), 317-321.

Santoso, U., Kubo, K., Ota, T., Tadokoro, T., and Maekawa, A. (1996). Nutrient composition of kopyor coconuts (Cocos nucifera L.). Food Chemistry, 57(2), 299-304.

Saxena, A. P., and Vyas, K. M. (1986). Antimicrobial activity of seeds of some ethnomedicinal plants. Journal of
Economic and Taxonomic Botany, 8(2), 291-300.

Sayed-Ahmad, B., Talou, T., Saad, Z., Hijazi, A., and Merah, O. (2017). The Apiaceae: ethnomedicinal family as source for industrial uses. Industrial crops and products, 109, 661-671.

Shahwar, M. K., El-Ghorab, A. H., Anjum, F. M., Butt, M. S., Hussain, S., and Nadeem, M. (2012). Characterization of coriander (Coriandrum sativum L.) seeds and leaves: volatile and non volatile extracts. International journal of food properties, 15(4), 736-747.

Shaw, M., and Srivastava, B. S. (1964). Purine-Like substances from coconut endosperm and their effect on senescence in excised cereal leaves. Plant physiology, 39(4), 528.

Sriti, J., Wannes, W. A., Talou, T., Vilarem, G., and Marzouk, B. (2011). Chemical composition and antioxidant activities of Tunisian and Canadian coriander (Coriandrum sativum L.) fruit. Journal of essential oil research, 23(4), 7-15.

Sudheer, K. P., and Indira, V. (2007). Post harvest technology of horticultural crops (Vol. 7). New India Publishing. p137.

Thippeswamy, N. B., and Naidu, K. A. (2005). Antioxidant potency of cumin varieties - cumin, black cumin and bitter cumin - on antioxidant systems. European food research and technology, 220(5-6), 472-476.

Vigliar, R., Sdepanian, V. L., and FagundesNeto, U. (2006). Biochemical profile of coconut water from coconut palms planted in an inland region. Jornal de pediatria, 82(4), 308-312.

Wangensteen, H., Samuelsen, A. B., and Malterud, K. E. (2004). Antioxidant activity in extracts from coriander. Food chemistry, 88(2), 293-297.

Wichlt M.W. (1994). Herbal drugs and phytochemicals. Stuttgart: Medpharm 
GmbH Scientific Publishers..pp-54

Yong, J. W., Ge, L., Ng, Y. F., and Tan, S. N. (2009). The chemical composition and biological properties of coconut (Cocos nucifera L.) water. Molecules, 14(12), 5144-5164.

Zare-Shehneh, M., Askarfarashah, M.,
Ebrahimi, L., Kor, N. M., Zare-Zardini, H., Soltaninejad, H., and Jabinian, F. (2014). Biological activities of a new antimicrobial peptide from Coriandrum sativum. Int J Biosci, 4(6), 89-99.

\section{How to cite this article:}

Srishti Saklani, Mahipal Singh Tomar and Shumaila Siddiqui. 2019. Preparation of a Nutritious and Healthy RTD (Ready To Drink) Beverage Enriched with Natural Anti Oxidants. Int.J.Curr.Microbiol.App.Sci. 8(05): 2184-2192. doi: https://doi.org/10.20546/ijcmas.2019.805.257 